\title{
The Effectiveness of Semantic Mapping Strategy to Improve Students' Writing Skill on Recount Text in Language Dormitory
}

\author{
Albadri 1), Linda Imamatul Rosyidah 2) \\ 1,2 English Department, Social and Humanity Science Faculty, University of Ibrahimy \\ Email Correspondence : badriabladri@gmail.com
}

\section{A R T I C LE INF O}

\section{Keywords:}

Semantic Mapping Strategy

Writing Skill

Recount Text

\section{Article History:}

Received : 18 December 2021

Accepted : 20 January 2022

Published : 14 February 2022

\section{A B S T R A C T}

Semantic Mapping is a simple strategy used by students by clustering words starting with determining the main idea according to the theme they will tell and supported by words related to the main idea. this study aims to (1) The influence of semantic mapping strategy on students' ability to write recount text (2) to test the effectiveness of the semantic mapping strategy of students' ability to write recount text. The method used in this research is a Quasi-Experimental method with a Non-equivalent design. Data obtained through tests and documentation. The sample of this research was 15 students of Elementary. based on the results of the pre-test and post-test, students' ability in writing recount texts increased by 38 , which is the difference between the control class' post-test average score of 48 and the experimental class's post-test average score of 86. Furthermore, based on the statistical calculation of 0.05 , the value of Sig. $<0.05(0.045<0.05)$, means that the use of the Semantic Mapping strategy is effective in improving the ability to write recount text. 


\section{Introduction}

The most important part of human life to communicate, express ideas, feelings, and opinions, either individually or universally is language. The communication tool is used by every individual daily. Language is an inseparable element of gear for the people in expressing their opinions through speaking with a sound, letters, words, phrases, and sentences because they have got a thought that cannot be equated with other creatures (Shahhoseiny, 2013, p. 2235). Humans as residing beings did not separate from the Language in any conditions because language is always connected to humans in his life. Humans as residing beings did not separate from the language in any conditions because language is always connected to humans in his life. As a human being, it is obligatory to learn even though language has a plural nature and is difficult to understand as a result. (Stanlsw James, Salzmann Zdenek, 2018, p. 2)

In language learning, four language skills must be mastered those are listening, speaking, reading, and writing skills. So, linguistics and language cannot be separated because they are interrelated in language learning which studies the sounds produced by humans. Language is a tool in communication to express opinions in writing or speaking through vocabulary, sound, form, and arrangement in grammar.(Siregar, 2017, p. 27). In other words, language learning is directed at communication skills in various situations and language learning aims to improve students' language skills. Among the four skills, writing skill is productive and include. Writing is a difficult or complex skill and requires creativity. Students are expected to be able to express ideas, ideas, experiences, and opinions in various writings.

Based on the observation in the Language Dormitory of Salafiyah-Syafi'iyah Sukorejo, the researcher found some problems from the results of writing students are: The first problem that is found by the researcher is writing is a difficult skill. The teacher gave them the example of recounting text and explained how to make it. When the teacher asked them to write with their idea, they did not know what will be written, some students were confused and some did not have ideas. After trying to write a recount text, there were many errors in the text such as spelling, capitalization, grammar, and tenses.

The second student improper word selection, repeated words in one sentence, and difficulty in developing and stringing words to form good writing. And the third problem is related to technique or strategy. Various techniques can apply in the classroom and to arrive at that ability is required a lot of writing practice in daily life.

One of the efforts to improve the quality of education should be in line with improving the learning process. If these efforts are made, then the improvement of learning examines the learning process conducted by educators and students. To improve the quality that can be done is to use a learning strategy that corresponds to language learning, especially for writing skills.

Learning strategy is general approach and measure series that will be taken by the teacher to choose the learning method which agrees with the lesson. Therefore, the researcher used, strategy that is appropriate to language learning to improve writing skills in English. (Wael et al., 2018, p. 66)The learning strategy is semantic mapping, which is a strategy used by making the concept of a word whose meanings are interrelated and semantic mapping consists of a very broad category of graphic organizers and can be used in a wide variety of subject areas to help students understand relationships and develop broad-topic concepts,(Hapsari et al., 2020).

\section{Methods}

In this study, the researcher used a quantitative approach with the experimental method. (Jacobson et al., 2019, p. 114), (as cited by Kapur, Hung, Jacobson, \& Voiklis; Suthers \& 
Hundhausen, 2003), (Sugiono, 2014) This method was used because of the influence of the independent variable on the dependent variable in the control condition. This research used a Quasi-experimental method with a Non-equivalent design. In this design. (Creswell \& Creswel, 2018). There is a pre-test and post-test so that the effect of the treatment can be calculated by comparing the value of the data test.(Sugiyono, 2018) Thus the treatment results can be found to be more accurate in this design, the research was conducted in one class. The implementation is done by doing a pre-test, namely a test that is carried out before the treatment, then the treatment is carried out by the pos-test.(Kartika et al., 2020, p. 2) (As cited Sudjana, 2011)

This research was held at the Language Dormitory of Salafiyah-Syafi'iyah Boarding School Sukorejo, exactly in Elementary B and D class. The population is 57 students of the Elementary class of language dormitory of Salafiyah-Syafi'iyah Boarding School and the sample of this study is 15 students of the experimental and control class.

A research instrument is a tool used to measure the observed natural and social phenomena, (Sugiono, 2014). The instrument is used to measure the variables in the study. In this study, researchers used the following instruments:

a. Test

The researcher used the test instrument twice, namely (pretest) and (posttest). The pretests are conducted by asking students to write stories about their personal experiences. This pretest aims to determine the ability of elementary B students in writing recount text. While the posttest is carried out after the implementation of the semantic mapping learning strategy. In the posttest students are asked to write stories, this posttest aims to determine the extent to which students' writing skills in the recount text after the treatment is applied.

\section{b. Documentation}

The data related to this study will be research documentation. Documentation media in this study are pictures, names of the respondent, the value of the test, and lesson plan.

\subsection{Data Analysis Technique}

a. The Validity Of The Research Instrument

The instrument is valid if it can measure what is desirable and it can reveal the data of the variable appropriately(Sugiyono, 2018), and writing test is the instrument that is used in this research. The validity is used to determine how the instrument has reflected the result. The validity was applied in the writing test was content and constructs validity.

b. The Reliability of the Research Instrument

The reliability indicates the level refers to the consistency or stability of the test scores.(Arikunto, 2010),(Andrianis et al., 2018). It means that the scores from an instrument are stable and consistent. In this research, the researcher used content reliability to measure the reliability of writing tests. The measuring instrument used to measure reliability is the Cronbach Alpha (a) statistical test.

\subsection{Descriptive Analysis}

The descriptive analysis employs the result of the mean and the standard deviation. 
a. Mean is a commonly used measure of central tendency because the mean takes all scores and the mean is the same as the average of the score.

b. Median is the average score from data that has been well organized.

c. Modus which is shortened by Mo is a value that appears on the data.

d. Standard deviation is used to measure variability.

\subsection{Inferential Analysis}

a. Test of Normality

Test of normality aims to determine whether the distribution of responses has a normal distribution or not.(Irianto, 2007, p. 275)

b. Test of Homogeneity

The test of Homogeneity aims to determine whether the sample is taken from the population has the same variance or doesn't show any significant differences from each other.

c. T-test

After getting the data from the pre-test and post-test from the experimental and control classes, the researcher needs to find out the differences score using the semantic mapping strategy. Here, the two classes are compared to the independent variable, the experimental class is the $\mathrm{X}$ variable and the control class is the $\mathrm{Y}$ variable. The researcher used paired sample of the t-test through SPSS 16. It is used to know whether students improve their scores or not.(Fitriyani, 2016, p. 203).

\section{Result}

\subsection{Data Description}

a. Data Description of Control and Experimental Class' Pre-test

The table will describe the minimum, maximum, mean, median, modus, and standard deviation of control and experimental class' pre-test value.

Table 1. Pre-test of Control and experimental class

\begin{tabular}{lll}
\hline Description & Control & Experiment \\
\hline Minimum & 35 & 35 \\
Maximum & 60 & 57 \\
Mean & 47 & 48 \\
Median & 45 & 45 \\
Modus & 40 & 40 \\
Standard Deviation & 8.297 & 7.243 \\
\hline
\end{tabular}

b. Data Description of Control and Experimental Class' Post-test

The table will describe the minimum, maximum, mean, median, modus, and standard deviation of control and experimental class' post-test value. 
Table 2. Post-test of control and experiments

\begin{tabular}{lll}
\hline Description & Control & Experiment \\
\hline Minimum & 40 & 80 \\
Maximum & 78 & 94 \\
Mean & 48 & 86 \\
Median & 47 & 86 \\
Modus & 45 & 85 \\
Standard Deviation & 8.991 & 4.190 \\
\hline
\end{tabular}

\subsection{Data Analysis}

a. The Validity Test

The validity test is useful to determine the suitability of the questionnaire used by researchers to test data obtained from respondents or research samples. (Zein et al., 2019). This provided consistent measures of precisely the abilities that are interesting to be valid. It means that a test could be valid if it already measured what was supposed to measure.

From the results of the SPSS test, it can be seen that the Sig (2-tailed) value of the $X$ variable and $Y$ variables is less than $<0.05$. The result from the value of rcount and rtable is that the value of rcount $>$ rtable. The value of rtable is 0.4124 obtained from the value of $\mathrm{N}-2=15-$ $2=13$. The number 13 when viewed in the rtable through the significance value for one direction of 0.05 is 0.04409 . So, the conclusion is each indicator of the $\mathrm{X}$ and Y variables is valid so that the data can be used for the next stage.

b. The Reliability Test

The reliability test was one of the important elements of test quality. A test was said reliable if the scores of students were consistent and accurate. The reliability test serves to determine the level of consistency reliability used by researchers so that the criteria of the writing test is used to measure research variables. The result of the reliability test showed in the tables below.

Table 3. Reliability Statistics of Variable X

\begin{tabular}{cc}
\hline Cronbach's Alpha & N of Items \\
\hline, 562 & 3 \\
\hline
\end{tabular}

Table 4. Reliability Statistics of Variable Y

\begin{tabular}{cc}
\hline Cronbach's Alpha & N of Items \\
\hline, 867 & 7 \\
\hline
\end{tabular}

The researcher calculated the reliability of variables X and Y using Cronbach's Alpha. From the variable test above, it can be seen that overall variables have Cronbach's Alpha values > 0.006 , the reliability score of Variable $\mathrm{X}$ is 0.954 and for variable, $\mathrm{Y}$ is 0.867 which are as follows that variables value are $>0.006$. 
c. Homogeneity Test

Based on the calculation of normality, the writer got the result that all data in pre-test and post-test of both experiment class and controlled class have been normality distributed. The result that the writer got can be seen in the table below:

Table 4. Test of Homogeneity of Variable Post-Test

\begin{tabular}{lllc}
\hline Levene Statistic & $\mathrm{df1}$ & $\mathrm{df2}$ & Sig. \\
\hline .026 & 1 & 28 & .874 \\
\hline
\end{tabular}

It can be seen that the result of the homogeneity test Lavene Statistic score shows 0.26 by significance 0.874 . Therefore, the significance score is higher than $0.05(0.874>0.05)$. It means the experimental and control class were homogenous.

d. Normality Test

1) The Control Class

The pre-test score of test normality in writing skills in the control class is shown in the table below.

Table 5. Pre-Test of Normality

\begin{tabular}{lcllllll}
\hline & \multirow{8}{*}{ class } & \multicolumn{3}{c}{ Kolmogorov-Smirnova } & \multicolumn{4}{l}{ Shapiro-Wilk } \\
& & Statistic & Df & Sig. & Statistic & df & Sig. \\
class & 1 & .217 & 15 & .056 & .887 & 15 & .060 \\
a. Lilliefors Significance Correction & & & & \\
\hline
\end{tabular}

Based on the table above, it can be seen that the significance from the normality test of Shapiro-Wilk shows 0.060 . Therefore, the significant score is higher than $0.05(0.060>$ 0.05). It means that $\mathrm{H} 0$ is accepted so the data is normally distributed.

The post-test score of test normality in writing skills in the control class is shown in table below. From the table below, it can be seen that the significance from the normality test of Shapiro-Wilk shows 0.415 . Therefore, the significant score is higher than 0.05 $(0.415>0.05)$. It means that $\mathrm{H} 0$ is accepted so the data is normally distributed.

Table 6. Post-Test of Normality

\begin{tabular}{|c|c|c|c|c|c|c|c|}
\hline & \multirow{2}{*}{ Control } & \multicolumn{3}{|c|}{ Kolmogorov-Smirnova } & \multicolumn{3}{|c|}{ Shapiro-Wilk } \\
\hline & & Statistic & Df & Sig. & Statistic & $\mathrm{df}$ & Sig. \\
\hline Post-test & 1 & .182 & 15 & $.200 *$ & .940 & 15 & .415 \\
\hline
\end{tabular}

2) Experimental Class

The experimental class is a class taught using semantic mapping strategy in writing recount text. The subject in the experimental class is 15 students. The table showed about normality test of the experimental class. Based on the table below, it can be seen that the 
significance from the normality test of Shapiro-Wilk shows 0.256 . Therefore, the significant score is higher than $0.05(0.256>0.05)$. It means that $\mathrm{H} 0$ is accepted so the data is normally distributed.

Table 6. Pre-Test of Normality

\begin{tabular}{lcccclcc}
\hline & \multicolumn{8}{c}{ Class } & \multicolumn{3}{c}{ Kolmogorov-Smirnova } & \multicolumn{3}{l}{ Shapiro-Wilk } \\
& & Statistic & Df & Sig. & Statistic & df & Sig. \\
class & 1 & .186 & 15 & .174 & .928 & 15 & .256 \\
a. Lilliefors Significance Correction & & & & \\
\hline
\end{tabular}

The post-test score of test normality in writing skills in the control class is shown in table 4.10 below. It can be seen that the significance from the normality test of ShapiroWilk shows 0482 . Therefore, the significant score is higher than $0.05(0.482>0.05)$. It means that $\mathrm{HO}$ is accepted so the data is normally distributed.

Table 7. Post-Test of Normality

\begin{tabular}{lllllllc}
\hline \multicolumn{1}{c}{ class } & \multicolumn{3}{c}{ Kolmogorov-Smirnova } & \multicolumn{3}{c}{ Shapiro-Wilk } \\
& & Statistic & Df & Sig. & Statistic & df & Sig. \\
class & 1 & .144 & 15 & $.200^{*}$ & .947 & 15 & .482 \\
*. This is a lower bound of the true significance. \\
a. Lilliefors Significance Correction
\end{tabular}

\subsection{Data Interpretation}

The table below will show the result T-test (Independent T-test) using SPSS from the value of control and experimental class.

Table 8. Independent Samples Test

\begin{tabular}{|c|c|c|c|c|c|c|c|c|c|c|}
\hline & & $\begin{array}{l}\text { Levene's } \\
\text { for Equ } \\
\text { Variance }\end{array}$ & $\begin{array}{l}\text { Test } \\
\text { lity of }\end{array}$ & & & & t-test for Equ & uality of Mear & & \\
\hline & & $\mathrm{F}$ & Sig. & $\mathrm{t}$ & $\mathrm{df}$ & $\begin{array}{l}\text { Sig. (2- } \\
\text { tailed) }\end{array}$ & $\begin{array}{c}\text { Mean } \\
\text { Difference }\end{array}$ & $\begin{array}{l}\text { Std. Error } \\
\text { Difference }\end{array}$ & $\begin{array}{r}95 \% \mathrm{Co} \\
\text { Interv } \\
\text { Diffe }\end{array}$ & $\begin{array}{l}\text { lfidence } \\
\text { l of the } \\
\text { ence }\end{array}$ \\
\hline & & & & & & & & & Lower & Upper \\
\hline \multirow{2}{*}{ NGain_Precent } & $\begin{array}{c}\text { Equal } \\
\text { variances } \\
\text { assumed }\end{array}$ & 4.382 & .045 & 11.398 & 28 & .000 & 67.41529 & 5.91485 & 55.29928 & 79.53130 \\
\hline & $\begin{array}{c}\text { Equal } \\
\text { variances } \\
\text { not assumed }\end{array}$ & & & 11.398 & 21.812 & .000 & 67.41529 & 5.91485 & 55.14251 & 79.68807 \\
\hline
\end{tabular}


The result is if Sig. < insignificant degree of 0,05, in the table showed that Sig $0.045<0,05$. So, Ho (null hypothesis) is rejected. It means that the rates of the mean posttest score of the experimental group are higher than the control group. The use of semantic mapping strategy is effective towards writing skills on recount text.

\section{Discussion}

Based on the computation of the post-test result in the control class Writing is a complex and difficult skill. It needs more effort to study this skill. Regarding the research which was done in Language Dormitory of Salafiyah-Syafi'iyah Sukorejo. The researcher used a simple strategy to Facilitate students in learning writing skills and to examine the effectiveness of this strategy, and It was considered that there is a significant difference between students' writing skills taught using semantic mapping strategy and those that didn't teach using semantic mapping strategy.

In the control class, it is known that the maximum score is 78 , the minimum score is 80 , the average score is 48 , the median 47 , and the standard derivation 8.991 . Therefore, in the experimental class from the result of the post-test, the data showed the highest score achieved by students is 94 and the lowest 80. By using SPSS 16 on descriptive, it is known that the average score (mean) achieved by students in the experimental class post-test is mean to 86 , median 86 , standard derivation 4.190 .

From the mean between the control and experimental class, it is known that the value of the experimental class is higher than the control class. So, the value between classes that used semantic mapping strategy and didn't is different. There is the effectiveness in using semantic mapping strategy in Language Dormitory of Salafiyah- Syafi'iyah Boarding School.

To determine the differences score using semantic mapping strategy used T-test (Independent T-test), The result is if Sig. $<$ in a significant degree of 0,05, in the table showed that Sig. 0,045<0.05. So, Ho (null hypothesis) is rejected. It means that the rates of the mean posttest score of the experimental class are higher than the control class. The use of semantic mapping strategy is effective towards writing skills on recount text. In this Study, There is effectiveness significantly in the use of semantic mapping strategy on students' writing skills on recount text in Language Dormitory of Salafiyah-Syafi'iyah Boarding School Sukorejo. This research is relevant to the research done by Indah Sri W by the title "The Effect of Semantic Mapping Strategy On Writing Report Text Of Observation With Cognitive Field Independent", the result from this research showed that $75 \%$ of semantic mapping strategies influential to students' outcome of writing report text of observation with cognitive field independent. (Wilujeng et al., 2017, p. 237)

\section{Conclusion}

Based on the results of the research and discussion that has been presented in the previous chapter. Which aim to increase students' writing skill on recounting text which is gotten by students in writing recount text through semantic mapping there is the difference significantly. The outcome of students who learned to use semantic mapping is increased than students who learned writing recount text without semantic mapping.

The writing outcomes of semantic mapping are shown by the results of the T-test of experimental class post-test and control class $<0,05$. So, there is a significant difference between students' writing skills taught using semantic mapping and those taught not using semantic mapping. The result shows that the semantic mapping strategy is an effective way to be used in teaching writing for Elementary students of Language Dormitory. 


\section{References}

Andrianis, R., Anwar, M., \& Zulwisli, Z. (2018). Suharsimi Arikunto (2010). Prosedur Penelitian Suatu Pendekatan Praktik. Jakarta: Rineka Cipta. Voteteknika (Vocational Teknik Elektronika Dan Informatika), 6(1).

Arikunto, S. (2010). Dasar-dasar Evaluasi Pendidikan. Jakarta: Bumi Aksara. 2010. In Manajemen Penelitian.

Creswell, J. W., \& Creswel, J. D. (2018). Research Design - Qualitative, Quantitative, and Mixed Methods Approaches. In Journal of Chemical Information and Modeling.

Fitriyani, E. (2016). The Effectiveness Of Crossword Puzzle In Learning Vocabulary (A Quasyexperimental Study at the Seventh Grade Students of MTs. Muhammadiyah 1 Ciputat).

Hapsari, F. S., Astuti, N. T., \& Frijuniarsi, N. (2020). Efektivitas Stategi Pembelajaran "Semantic Mapping" Dalam Meningkatkan Penguasaan Kosakata Bahasa Inggris Mahasiswa. SAP (Susunan Artikel Pendidikan), 4(3), 260-266. https://doi.org/10.30998/sap.v4i3.6290

Irianto, A. (2007). Statistik: Konsep dasar dan aplikasinya.

Jacobson, M. J., Levin, J. A., \& Kapur, M. (2019). Education as a Complex System: Conceptual and Methodological Implications. Educational Researcher, 48(2), 112-119. https://doi.org/10.3102/0013189X19826958

Kartika, Y., Swistoro, E., \& Firdaus, M. L. (2020). Application of Jigsaw Cooperative Learning Model on Spectroscopy Subject. Bencoolen Journal of Science Education and Technology, 1(1). https://doi.org/10.33369/bjset.v1i1.11175

Shahhoseiny, H. (2013). Differences between language and linguistic in the ELT classroom. Theory and Practice in Language Studies, 3(12), 2234-2239. https://doi.org/10.4304/tpls.3.12.2234-2239

Siregar, S. (2017). RiliThe influence of dislect on the student's in speaking ability. JOALL (Journal of Applied Linguistics and Literature)Ournal of English Language Teaching, 5(1), 27-36. http://e-journal.metrouniv.ac.id/index.php/pedagogy

Stanlsw James, Salzmann Zdenek, A. N. (2018). Language, Culture, and Society. In An Introduction to Linguistic Anthropology (7th ed., p. 451). Routledge. http://taylordfrancis.com

Sugiono, P. D. (2014). Metode penelitian pendidikan pendekatan kuantitatif.pdf. In Metode Penelitian Pendidikan Pendekatan Kuantitatif, Kualitatif Dan R\&D.

Sugiyono. (2018). Prof. Dr. Sugiyono. 2018. Metode Penelitian Kuantitatif, Kualitatif, dan R\&D. Bandung: Alfabeta. Prof. Dr. Sugiyono. 2018. Metode Penelitian Kuantitatif, Kualitatif, Dan R\&D. Bandung: Alfabeta.

Wael, A., Asnur, M. N. A., \& Ibrahim, I. (2018). Exploring students' learning strategies in speaking performance. International Journal of Language Education, 2(1), 65-71. https://doi.org/10.26858/ijole.v2i1.5238

Wilujeng, I. S., Suyitno, I., \& Martutik, M. (2017). Pengaruh Strategi Pemetaan Semantik terhadap Hasil Belajar Menulis Teks Laporan Hasil Observasi Siswa dengan Gaya Kognitif yang Berbeda. Jurnal Pendidikan: Teori, Penelitian, Dan Pengembangan, 2(9), 1231-1237.

Zein, S., Yasyifa, L., Ghozi, R., Harahap, E., Badruzzaman, F., \& Darmawan, D. (2019). Pengolahan dan Analisis Data Kuantitatif Menggunakan Aplikasi SPSS. Jurnal Teknologi Pendidikan Dan Pembelajaran, 4(1). 